\title{
The principle of activity specificity in episodic memory
}

\author{
Ekaterina E.Vasyukova ${ }^{a}$, Olga V. Mitina ${ }^{a, b}$ \\ ${ }^{a}$ Lomonosov Moscow State University, Moscow, Russia \\ ${ }^{b}$ Moscow City University of Psychology and Education, Moscow, Russia
}

\begin{abstract}
The effect of chess skill, age, and conditions for memorization on the efficiency of the recall of sequences of opening chess moves was studied. Thirty-nine chess players of different skill levels (from category 2 to grandmaster) and ages (from 17 to 81 years old) were divided into four groups (ELO > 2000 before and after the age of 40; ELO $<2000$ before and after the age of 40). They were asked to remember the sequences of moves under three conditions (passive perception, use of imagination, physical generation of moves) and to recall (reproduce) the sequences by making the moves. It turned out that in the passive-perception condition the younger chess players, on the one hand, and the more highly skilled players, on the other, recalled the moves significantly better than did the other groups. Also, in almost all the groups of players the efficiency of memory grew as the condition for memorization and that for reproduction converged, with the highest growth rate found among chess players older than 40 years with ELO $>2000$. The current memory of the chess experts was to a greater extent mediated by opening schemes and knowledge than was that of the intermediate players. A hypothesis about the activity specificity of the coding in episodic memory was confirmed and concretized.
\end{abstract}

Keywords: episodic memory, principles of the specificity of coding and activity specificity, chess skill, age, situations for imprinting the sequences of opening chess moves, structural modeling

In psychology in Russia chess has repeatedly been the model for studying the fundamental problems of thinking; memory; creative activity and its motivation; emotional, sense, and personal regulation; and creative activity as changed by information technologies (Bartashnikov, 1988; Blumenfeld, 1948 ; Levit, 1988; Tikhomirov, 1967, 1984; Vasilyev, 1980; Vasyukova, 1986, 1995,1999, 2001, 2008, 2009a,b, 2012a; Vinogradov, 1972; and others). The problem of thinking and communication has been studied by using information on chess playing: Krogius (1986) studied interpersonal cognition in conflict activities; Kurochkina (1997) analyzed the impact of direct communication with a "significant other" on creativity. 
Blumenfeld (1948) described the thinking of a chess player as practical and connected with the emotional-volitional sphere. The thinking of a chess player is visual and has a limited time frame. Experience of the past is the basis of the thinking process. Among the semantic entities, which are formed in experience, visual and verbal ideas are identified. A distinction is made between thinking in the combinational and in the positional game. The two main forms of intellectual activity in the combinational game are calculation and "vision." In the positional game, a plan in which verbal thinking dominates plays a significant role. However, even in a positional game the thought process is not confined to reasoning.

According to Tikhomirov (1967), "Chess is a special case of processes of selection of a specific practical action in a concrete situation on the basis of studying the peculiarities of this situation. In practice this process is included in all types of human activity" (p. 176).

In the works of Tikhomirov and his disciples in the field of the psychology of thinking, a breakthrough occurred in the sphere of the unconscious mental processes, in many respects thanks to their use of chess as a model object. The very idea of thinking as a purely rational process changed; a semantic content was added to its composition. Thinking has been regarded as an integral activity with unconscious components, motivation, and emotional regulation. Thanks to the emergence of new research methods the possibilities of studying thinking have greatly expanded. There are new concepts: operational sense (unverbalized and verbalized), dynamic conceptual system, and psychological system. The concepts of goal formation and sense formation are being intensively developed.

In this article, the episodic memory and the principle of the specificity of coding, which acts in episodic memory, are studied by using relevant information from chess players. We interpret this principle from the position of the theory of activity.

Episodic memory, which stores the episodes of the past, has been the object of most of the psychological research on memory, from the work of H. Ebbingaus to that of modern cognitive psychologists. Its functioning is closely linked with other kinds of long-term memory, both procedural and semantic. According to E. Tulving, procedural memory corresponds to anoetic consciousness (unconscious regulation), semantic memory corresponds to noetic consciousness ("I know"), and episodic memory corresponds to autonoetic consciousness ("I remember") (Nourkova, 2008).

In episodic memory the principle of "specificity of coding" applies: the availability of information from the past is determined by the coincidence of the "key" elements of the encoding and the retrieval of that information.

However, "the principle of specificity implies the passivity of the subject and therefore recognizes the conditionality of the accuracy of episodic memory for external situational reasons" (Nourkova, 2008, p. 211). From the point of view of Nourkova, the most adequate interpretation is the combined one, which should be called "the principle of activity specificity." According to this interpretation, those aspects of the information flow that correspond to ongoing activities are stably encoded. In fact, the activity interpretation of the principle of specificity in episodic memory reflects the active nature of memory.

In a number of works, domestic and foreign psychologists have observed the dependence of the productivity of memory on the specificity of the current activity. 
With regard to involuntary memorizing Zinchenko (1998) has shown that its basic form is a product of purposeful activity, and that which corresponds to the goal of the activity is better remembered than the conditions. In a special series of experiments Zinchenko proved that the essence of involuntary memorizing is not in the attention to the object but in the activity of the subject. The subject reflects reality and appropriates any reflection of reality as the subject of the action, not the subject of the passive contemplation.

The work of Zinchenko served as the starting point for creating a level approach to the study of memory (F. Kreyk and R. Lockhart). According to this approach, memory is a by-product of information processing. There are several levels of such processing: sensory, perceptual, semantic, and attribution to oneself. It has been established that the deeper the processing, the stronger the trace in memory (see Velichkovsky, 2006, Vol. 1, pp. 375-382).

In a study by B. M. Velichkovsky, F. Kreyk, and B. Chellis the question was whether it is possible to establish a correspondence between the different levels of processing for encoding and the leveling mechanisms in the testing of memory (Velichkovsky, 2006, Vol. 1, pp. 408-411). Experimentally different forms of encoding (from the perceptual to the semantic and metacognitional) are correlated with the largest variety of tests of memory. The conclusion is that there is a more pronounced effect of the actual levels of processing compared with the effects of the specific encoding (i.e., the conformity of the conditions of coding to a certain test of memory), but only for direct tests.

Istomina (1998) studied the development of voluntary memory in preschoolers and showed that, in play activity, the productivity of memory is higher than in laboratory tests.

Nourkova $(2009,2011)$ explored the phenomenological features of autobiographical memory depending on the sense aspect of the actual activity. In April and October 2002, she collected material on Muscovites' recollections of the terror attacks in Moscow in September 1999. She found that with the increasing need for safety the recollections of these events became more vivid and detailed. The principle of "activity-based encoding specificity," formulated by Nourkova earlier, was updated: this principle "assumes the determination of mnemic processes by matching the material and the content of the different regulators of relevant activity (values, motives, goals, senses, ways of realization)" (Nourkova, 2009, p. 66).

In our opinion, the principle of activity-based encoding specificity may be applied not only to an actual activity but also to preceding activities. The coding of the material may take place in accordance with the specifics of the previous activitiesfor example, professional activity. And here it is expedient to turn to the problem of the acquisition of a masterful performance. In comparative studies of the peculiarities of the knowledge and cognitive processes of experts and beginners, the content and the role of practice, a "system of activities," were specially analyzed in the context of the acquisition of skills.

In early works regarding expertise that were based on research on chess, skill was directly associated with knowledge. Still, de Groot (1946/1978) showed that "world-class chess players were able to access a couple of superior alternative chess moves during their perception of the chess position, which implied pattern-based retrieval from memory rather than the results of an extensive search" (Ericsson, 
1996, p. 14). So the nature of expertise is connected not so much with thinking as with extensive and better organized knowledge. Grandmasters remember positions shown to them for a short time, but only when there is a meaningful arrangement of figures.

K. Ericsson and U. Kintch suggested that the development of expertise in a certain area leads to the weakening and even the disappearance of the impact of shortterm memory in information processing. Therefore, the processes of the encoding and retrieval of expert knowledge directly relate to long-term memory. Formed in the course of the accumulation of experience at the "interface" of perception and long-term memory, these processes are called "long-term working memory" (Velichkovsky, 2006, Vol. 1, p. 375).

Chase and Simon (1973) "found that about 10 years of preparation was necessary to attain an international level of chess skill" (the 10-year rule of necessary preparation). "However, ... the mere amount of experience is only a weak predictor of an individual's level of performance in a domain and thus 10 years of experience in a domain does not guarantee that expert performance is attained" (Ericsson, 1996, p. 10). “The laboratory analyses of expert performance revealed many complex mechanisms reflecting extreme adaptation to the task demands in the respective domains of expertise" (p. 18). As B.S. Bloom found in 1985, "In the development of expert performance it is possible to distinguish several stages in which the involvement in the domain progressively increases" (Ericsson, 1996, p. 19). The assumption that the various forms of higher performance can be theoretically explained by the limited number of common mechanisms was not confirmed. In the development of elite performance the most relevant activities were identified (deliberate practice).

A model of the factors important to skill acquisition was proposed by Charness, Krampe, and Mayr (1996). In accordance with it, external (social and informational) factors and internal (motivational and personal) factors affect the cognitive system (a combination of "software" and "hardware") through practice, and that impact leads to expert performance. Researchers emphasize the role of certain practices, such as «serious analysis alone», which are important not only for the acquisition of expert performance but also for its maintenance.

Among the important components of deliberate practice can be included the study of chess openings (Vasyukova, 2012b).

Here the questions include: Do other factors, such as practice, past activity, or age, interfere in the action of the principle of the specificity of coding in episodic memory? How necessary is it to speak about activity-based specificity? How do "situational" and "activity-based" specificity affect the efficiency of the reproduction of the material? How is activity specificity researched? Activities that place high demands on memory-as, for example, a chess game-are of special interest.

The first work on the peculiarities of the thinking and memory of master chess players was conducted at the end of the 19th century by Thédolu-Armand Ribot (Velichkovsky, 2006, Vol.2, p. 244), and the first psychogramme of a chess player was proposed in 1926 by I. N. D’yakov, N. V. Petrovsky \& P. A. Rudik (D’yakov, 1926). In it a strong chess memory was included among the 16 most significant qualities of a chess player. The advantage of chess as an object of research is, in particular, that an objective criterion of the evaluation of skill exists-the international rating scale. 
As shown in our study (Vasyukova, 2012a), with the advent of the computerization of chess, new problems arise, including those associated with memory, requirements for which are increasing. Here's how one of our subjects, international grandmaster S. S., formulates the problem:

The appearance of computers has led to an avalanche of opening theories. Many options that before were considered to be complex, confusing, playful are now analyzed up to the point of being clear, unambiguous, even the "naked kings." And all this should be remembered. That is, all the ambitious chess players have a lot of cramming [to do]. It is hard.

Here the following question arises: What are the factors that influence the effectiveness of memory? Among them can be skill, which is connected with deliberate practice in the subject area, age, the conditions for memorizing the information (passive perception, physical generation of moves, visualization), as well as the degree of conformity between the condition for memorizing and the condition for recalling.

\section{Research project}

The goal of our study was to determine the dependence of the recall of sequences of opening chess moves on different conditions for their memorization and on the qualifications and ages of the chess players.

The task of the research was to examine the correlation of the conditions for memorizing the sequences of opening chess moves, the age of the chess players, and their skill levels with the efficiency of access to this information in the most typical situation of recall: making the moves on the board.

\section{Subjects}

Thirty-nine chess players with different qualifications (from category 2 to grand master, average $\mathrm{ELO}^{*}(2028 \pm 303)$ and of different ages (from 15 to 81, average age $44.87 \pm 17.26$ ) were put in four groups. The cut-off point for the young and old groups was 40 years, and for the groups of experts (skilled) and nonexperts (low skills) it was $\mathrm{ELO}=2000$. Table 1 shows the number of subjects in each group. The number of females among the subjects in each group is in parentheses.

Table 1. Distribution of Subjects Among Four Categories According to Age and Skill Level

\begin{tabular}{|c|c|c|c|c|}
\cline { 2 - 5 } \multicolumn{1}{|c|}{} & \multicolumn{2}{c|}{ ELO } & \multirow{2}{*}{ Total } \\
\cline { 2 - 5 } \multicolumn{1}{c|}{} & $<\mathbf{2 0 0 0}$ & $>\mathbf{2 0 0 0}$ & \\
\hline \multirow{2}{*}{ Age } & $<\mathbf{4 0}$ & $10(0)$ & $9(4)$ & $19(4)$ \\
\hline & $>\mathbf{4 0}$ & $10(3)$ & $10(5)$ & $20(8)$ \\
\hline \multicolumn{2}{|c|}{ Total } & $20(3)$ & $19(9)$ & $39(12)$ \\
\hline
\end{tabular}

* ELO is a system used for ranking chess players. It reflects their degree of success in competitions and is the gold standard for mastery. 
We acknowledge that the gender distribution within each group is not well balanced. This imbalance occurs mainly because one group (low ELO and low age) includes only men, and even the other groups include relatively few women. The $\chi^{2}$ cross-tabulation test shows that the imbalance of genders and of skill levels is significant $(p$-value $=0.029)$. The age imbalance is not too critical $(p$-value $=0.2)$. Unfortunately the low number of female subjects did not allow us to perform separate analyses, and therefore we did not split the sample according to gender. But to be sure of the reliability of the results, in every case we checked the homogeneity of the unified sample on the analyzed variables.

\section{Method}

We analyzed the effectiveness of memorizing the sequences of chess opening moves in a two-part experiment. In the first part (memorization), the moves in a sequence were presented to the subjects under three conditions:

- the passive-perception condition (the first series of presentations): the initial position of the pieces and the physical moves of the pieces to their appropriate locations were shown on a computer screen

- the physical-generation condition (the second series of presentations): the moves were presented visually in chess notation, and the subjects made each move after it was presented using a lightpen (a photo-sensitive device connected to the computer and moved by hand to manipulate the pieces)

- the mental-generation condition (the third series of presentations): the moves were presented visually in chess notation, and the subjects were asked to imagine the moves before the pieces were moved by the computer

The experimental material consisted of six long (20 half-moves) sequences of opening chess moves in each series of presentations. In the first series, the next move sequentially for White and for Black on the computer screen appeared after 5 seconds. In the second series, the subject was given 5 seconds to make each move after it was presented in chess notation, but if the subject did not make a move during this time, it was performed automatically by the computer. In the third series, the subject was given 4 seconds to imagine the move; at the 5 th second the move was performed automatically by the computer.

In the second part of the experiment (recall), following the presentation of each move sequence, the board on the computer screen was reset to the initial position, and the subjects were asked to reproduce the sequence by moving the pieces with a lightpen.

From the point of view of the need to verify the hypothesis about the dependence of recall on the coincidence of the condition for memorizing (the first part of the experiment) and the condition for recollection (the second part of the experiment), the maximum accordance (coherence) was provided by series 2 , and the smallest by series 1 . 


\section{Analysis of the subjects' subjective reports}

We analyzed the subjects' evaluations of the easiness of the different series and their familiarity with the sequences of moves.

Working with the subjects' self-reports allowed us to "feel" the experiment and subsequently helped us to interpret the statistical results more adequately than we would otherwise have been able to do. Here we present some of the results of this systematizing work.

The more skilled players noticed an advantage to knowing the opening moves, and the less skilled stressed that their lack of such knowledge hindered them. Ten players with ELO $>2000$ indicated that they encountered mostly familiar openings, and nine players with ELO $<2000$ commented on the low number of familiar items and their lack of knowledge about openings. In other words, the memorization of the opening moves was mediated by the experts' knowledge of these openings. For players with lower skill such memorizing was not mediated by prior knowledge.

Younger players, compared with those who were over 40 years old, often noted that the first series was the easiest.

Subjects over 40 with not very high skills noted various confounding factors: inability to concentrate and poor fitness, lack of computer experience, lack of common chess notation, indicating the figures also, not only their movement (from ... to ...), the disconcerting role of the notation. For some players the second series was easier ("when you make the moves by hand"). Subject 23 indicated that all the series were equally difficult if the scheme was unknown. Three players (Subjects 23, 24, and 45) stressed that the unfamiliar positions were more difficult to memorize.

In the group of higher-skilled players over 40,5 of the 10 felt that it was equally easy to work in all three series. Only one person mentioned that the first series was the easiest one. Three players felt that there were more unfamiliar positions, and five people, on the contrary, said that the openings were known. Five people mentioned difficulties with attention, and two people noted shortcomings of memory.

In the group of highly skilled young players, three felt that the first series was easiest, three other people said the same about the second series, one person felt that both the first and the second series were easier than the third series, one person said that all the series were equally easy, and one person felt that which position (known or unknown) you memorized in each series was more important than any series as a whole.

Subject 53: "The first series was more simple; there were no distraction. The second series was more difficult. More factors make it more difficult because it loads your concentration.”

Subject 80: "The first series was easier; maybe I was fresher. The latest series was more difficult. The notation was distracting."

Subject 12: "The second series was easier. It may have been easier in the first series also because I was not distracted by the notation. I just had to watch and to memorize the sequence. The notation just distracted; in the second series that was not so, but it did not help a lot." 
Subject 27: “The second series was easier. It looked like I was playing my own game. The third series, when we wrote the move and thought. When one writes, one can imagine."

Subject 25: "The second series was easier; motor memory helped."

Subject 32: "The third series was the most difficult; there was more work."

Six people commented on the fact that they knew a lot of the openings:

Subject 25: “The knowledge of openings helps. I can't say that I know all the options. Memorize one word-the author of the system, the opening. I told myself 'Sveshnikov' and recollected the moves automatically. It is just a test of chess knowledge. In preparing it is necessary to learn a lot of variants. Knowledge is accurate; the order of the moves is significant. Naked memory is hard to hold onto. If a move makes sense, it is easier to hold it in memory. It is necessary to see the sense of the necessity of moves. I need to find the idea, the sense. If you delve into a position, players with a weak memory can memorize long sequences of moves. When memorizing one after another, one notices the nuances of the scheme, the tricks."

Subject 32: "I knew a lot of the openings."

Subject 27: "For the most part, the options were familiar. I memorize 30 halfmoves."

Subject 12: "There were from 80 to $90 \%$ familiar positions."

Subject 78: "In the third series there were less familiar situations. In the first and in the second series there were many more familiar ones."

Table 2. Subjects' evaluations of easiness/difficultness

\begin{tabular}{lccl}
\hline \multicolumn{1}{c}{ Type of answer } & Frequency & Percent & Descriptions of subjects \\
\hline The first series is the easiest & 8 & 20.51 & 6 subjects $<40$ years old \\
The second series is the easiest & 8 & 20.51 & 5 subjects with ELO $>2000$ \\
The third series is the easiest & 6 & 15.38 & 4 subjects with ELO $<2000$ \\
No answer & 7 & 17.95 & 6 subjects with ELO $<2000$ \\
All series are the same level of difficulty & 3 & 7.69 & ELO $<2000$ \\
All series are the same level of easiness & 4 & 10.26 & ELO $>2000$ \\
All series are similar; everything depends & 2 & 5.13 & ELO $>2000$ \\
on familiarity with the position & & & \\
The third series is the most difficult & 1 & 2.56 & $<40$ years old, ELO $>2000$ \\
Total & $\mathbf{3 9}$ & $\mathbf{1 0 0}$ & \\
\hline
\end{tabular}

In the group of young and less experienced players, three people said that all the series were equally difficult, and primarily this was due to a lack of knowledge. Three people said that the first series was easier than the other two (nothing was distracting); two people said the third series was the easiest (Subject 28: "They gave 
time to understand"); one person (Subject 56) said that "it was easier in the second series because I was playing an active role." Six people noted that unfamiliarity with the openings presented difficulties (Subject 15: "There was a low percentage of familiar positions"; Subject 58: "There was not any opening that I had played before"; Subject 74: "There were almost no familiar sequences, except Chelyabinsk's variant").

The resulting table of analysis estimates the easiness of the three series (Table 2).

\section{Analysis of the effectiveness of recall}

If we compare the objective data for the third series, the older and more experienced respondents remembered better than the younger and less experienced ones (the same trend occurred in the second series), but in the first series the younger and less experienced were more successful than the older and more experienced.

The best result in the first series was achieved by 2 people $(5.13 \%)$; in the second, by 22 people (56.41\%); in the third, by 8 people $(20.51 \%)$.

The best result in the first and second series was achieved by one person; five subjects got the best result in the second and third series. In all three series, the $100 \%$ result (remembered everything) was achieved by Subject 25, who also had the highest ELO.

Of those subjects who achieved the best result in the first series, $25 \%$ rated that series the easiest; $34.48 \%$ of the subjects who achieved the best result in the second series rated that series the easiest one. The least consistent evaluation of the easiness of a series was found among the subjects who achieved the best result in the third series: only $21.43 \%$ evaluated this series as the easiest one.

We ranked subjects according to reproduced half-moves in all three series in such a way that rank 1 was received by Subject 25, who achieved 100\% (360 reproduced half-moves), and Subject 52, who reproduced only 50 half-moves, got rank 39 (the worst result). Then we analyzed the subjects who got the 10 highest and the 10 lowest positions.

Among the participants with the best results, there were nine skilled (six young and three old) and only one less-skilled (young) player. The worst results belonged to eight inexperienced players (seven of whom were old and one was young) and two experienced old players (Subject 9 said that he had had a bad memory throughout his life, and Subject 4, the oldest participant at 81 years, reported a lack of playing practice.) The groups differed according to the self-reports. In the group with the top results there were no obvious preferences for the easiest series (one inexperienced player did not give an answer, two experienced young players preferred the first series as the easiest, two experienced differentage players said all the series had been equally easy; two experienced young players selected the second series as the easiest; two experienced old players preferred the third series; one experienced young player thought that the individual position determined the easiness more than any series as a whole). In the weak group, six players gave no answer; two old players with different skill levels considered the easiest series the second one; one inexperienced young player chose the first series as the easiest; and one inexperienced old player noted that all the series were equally difficult. 


\section{Results of the data analysis}

Analysis of variance with repeated measures (ANOVA) and structural equation modeling (SEM) were used for data analysis.

Samples were analyzed within each series. The results for recollecting different sequences within each series were highly consistent. As a measure of consistency Cronbach's alpha index was used. The cut-off value for Cronbach's alpha was chosen as 0.85 . This choice allowed us to average the results and to consider these averaged estimates as indicators of the memorization of chess moves in each series.

In Table 3 the descriptive statistics for the groups according to level of chess skill and age are presented.

Table 3. Descriptive statistics for the groups according to level of chess skill and age

\begin{tabular}{|c|c|c|c|c|c|c|c|c|c|c|c|c|}
\hline \multirow[b]{2}{*}{ ELO } & \multirow[b]{2}{*}{$\begin{array}{l}\text { Age } \\
\text { group }\end{array}$} & \multicolumn{3}{|c|}{$\begin{array}{l}\text { Series } 1 \text { Passive } \\
\text { viewing of the } \\
\text { moves on the } \\
\text { computer screen }\end{array}$} & \multicolumn{3}{|c|}{$\begin{array}{c}\text { Series } 3 \text { Imaging } \\
\text { of the moves, } \\
\text { which are } \\
\text { presented in } \\
\text { notations }\end{array}$} & \multicolumn{3}{|c|}{$\begin{array}{c}\text { Series } 2 \text { Physical } \\
\text { playing } \\
\text { moves }\end{array}$} & \multirow{2}{*}{\multicolumn{2}{|c|}{$\begin{array}{l}\text { Significant } \\
\text { difference be- } \\
\text { tween pairs } \\
\text { of the series }\end{array}$}} \\
\hline & & $\stackrel{\Xi}{\Xi}$ & 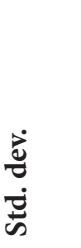 & 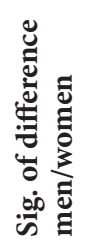 & छี & 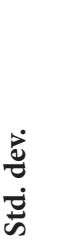 & 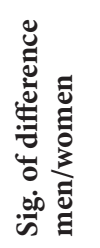 & 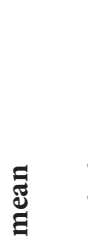 & $\begin{array}{l}\dot{\vec{\theta}} \\
\text { ¿ें }\end{array}$ & 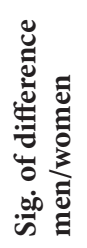 & & \\
\hline $\begin{array}{l}\text { lower } \\
2000\end{array}$ & $\begin{array}{l}\text { before } 40 \\
\text { years old }\end{array}$ & 13,07 & 3,69 & - & 13,68 & 4,49 & - & 15,12 & 4,96 & - & 0,022 & $0,9190,285$ \\
\hline $\begin{array}{l}\text { lower } \\
2000\end{array}$ & $\begin{array}{l}\text { older than } \\
40 \text { years } \\
\text { old }\end{array}$ & 7,88 & 4,34 & 0,07 & 8,45 & 4,67 & 0,07 & 9,97 & 6,56 & 0,07 & 0,083 & $0,5410,214$ \\
\hline $\begin{array}{l}\text { higher } \\
2000\end{array}$ & $\begin{array}{l}\text { before } 40 \\
\text { years old }\end{array}$ & 17,37 & 2,18 & 1,00 & 16,78 & 3,04 & 0,556 & 19,37 & 7,22 & 1,00 & 0,012 & $0,484 \quad 0,028$ \\
\hline $\begin{array}{l}\text { higher } \\
2000\end{array}$ & $\begin{array}{l}\text { older than } \\
40 \text { years } \\
\text { old }\end{array}$ & 12,08 & 4,54 & $=0,841$ & 15,02 & 4,42 & 0,841 & 15,85 & 4,98 & 0,690 & 0,008 & $0,0280,236$ \\
\hline
\end{tabular}

The results show clearly that in almost all the subgroups the greater the consistency between the condition for memorizing and the condition for recollecting, the better the recollecting. The only exception was the group of experienced young players. For this group results were higher in the series of minimal consistency (the first series) than in the intermediate series (the third series). However, the difference between these two series in the sample is not significant. It is quite possible that this result was due to the fact that the young players had reached the highest level of practice at the computer, the mode presented in the first series, so for them this mode was no less familiar than presenting the moves in notation. 
The table also presents the significance of the results' differences for each series for each gender. The Mann-Whitney test was used. It showed that men and women did not demonstrate significantly different results in all subgroups. Only for the group of low-skilled old players do we see $p$-values close to the conventional 0.05; in all other cases $p$-values are much bigger. For the group of lowskilled old players, the men were more successful than the women but still had the lowest results of any of the groups. So we can say that in the task of memorizing and recollecting men and women demonstrate similar results and can be unified into one group.

Further analysis of variance within and between subjects' characteristics was performed. The characteristics that could affect the quality of recall-age group, skill group, and the condition for remembering-were taken into account. The last factor was repeated. All factors are significant with $p$-value $<0.01$. If we compare the success of recollecting in each series separately, the significant influence of the factors of age and skill is found in all three cases. The younger as well as the more skilled players recollected better. Average results from Table 3 are presented in Figure 1 for clarity.

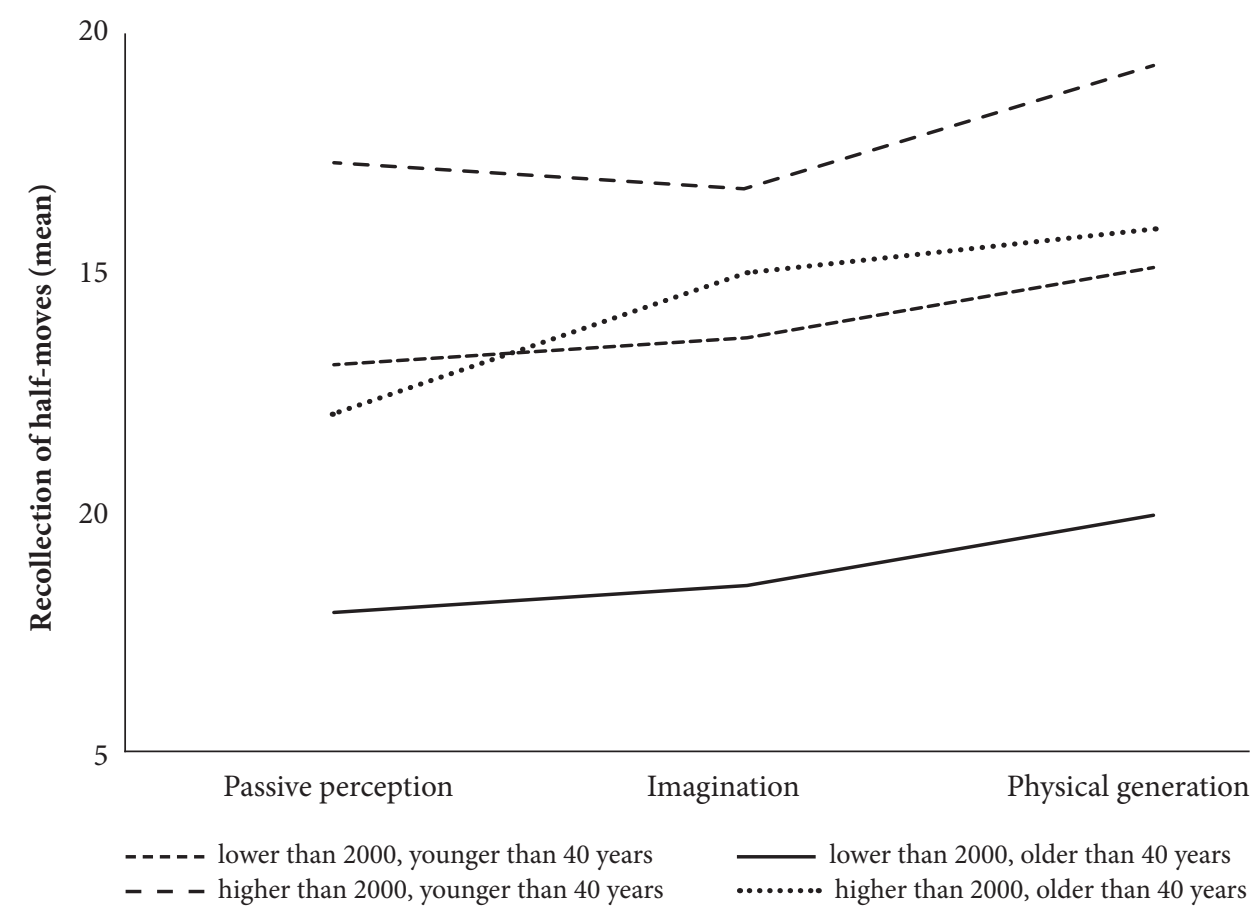

Figure 1. The dependence of recollection on age, skill level, and the condition for memorization.

The results of the pairwise comparison of the successfulness of recollecting in each series within each subsample are also presented in Table 3. The nonparametric Wilcoxon test was used. In each sample, sets of significant and insignificant differences are unique. In the group of those who were over 40 years 
old with low skills, there was better recollecting with increasing consistency in the conditions, but this result was not significant. For the group of respondents of the same age but with higher skills significantly lower results were obtained in the first series, and the difference between the second and third series was statistically insignificant.

Looking at the results for the highly qualified young players, we see a statistically significant better result in the second series, and for the young and not very experienced players there is a significant difference between results in the first and second series.

Structural equation modeling (SEM) provides the opportunity to more precisely distinguish the dynamic dependent variable from the independent variable (Bentler, 1995; Mitina, 2006). Because we wanted to identify and more precisely define patterns in recollecting moves imprinted under different conditions, the latent curve model (LCM), which reflects the dynamic of recollecting depending on the conditions for memorizing, could be used (Bollen \& Curran, 2006). Although ANOVA allows one to compare the means in each subsample and to show subgroup trajectories, the LCM allows one to study individual trajectories and to show how its parameters depend on individual characteristics. Our work (see Mitina, 2008) has shown that the LCM can be used to see how time determines not just dependent characteristics but any ranked variables. In our data such a variable was the condition for memorizing. Three series were ordered according to this variable.

To analyze the dynamics of recollecting and its dependence on the parameters of age and chess skills (experience), we used the following set of equations:

$$
\begin{aligned}
& \text { Recollecting in series } 1=1 F_{1}+0 F_{2}+E_{1} \\
& \text { Recollecting in series } 3=1 F_{1}+1 F_{2}+E_{2} \\
& \text { Recollecting in series } 2=1 F_{1}+2 F_{2}+E_{3} \\
& F_{1}=a_{1} \text { age }+a_{2} \text { experience }+a_{3} \text { age experience }+D_{1} \\
& F_{2}=b_{1} \text { age }+b_{2} \text { experience }+b_{3} \text { age experience }+D_{2}
\end{aligned}
$$

This model reflects the assumption that for each subject the dynamics of recollecting, which depend on the condition for memorizing, can be written as a linear function, which is characterized by an intercept corresponding to the level of recollecting in the first series and the growth rate (slope). The intercept corresponds to the latent variable $F_{1}$; the slope corresponds to the latent variable $F_{2}$. In this case, we assume that in the first series the coefficient of the slope is equal to 0 ; in the second series it equals +2 ; in the third series (the intermediate series) it equals +1 . However, in order to test how these latent variables depend on age and chess experience, we added equations 4 and 5. The coefficients $a_{i}$ and $b_{i}$ and their significances were calculated in the process of checking the fit of the model to the experimental data. It was found that the level of recollecting depended negatively on age: the younger a player was, the better was the level of recollecting in the first series; and the level of recollecting depended positively on chess experience (the higher the skill rating was, the better was recollecting in the first series). But the 
slope depended solely on the interaction of the in-between factors (age and experience) and reached the maximum for chess experts after they were 40 years old; see Figure 2). In other words, this group of players had the most success recollecting when the condition for recollecting and the condition for memorizing were similar, and the basic level of recollecting (recollecting from passive perception) was the best for the young experienced players; as a result when the recollecting condition was close to the memorizing condition, the old experienced players overtook the young ones, but in recollecting from passive perception the young experienced players were the best.

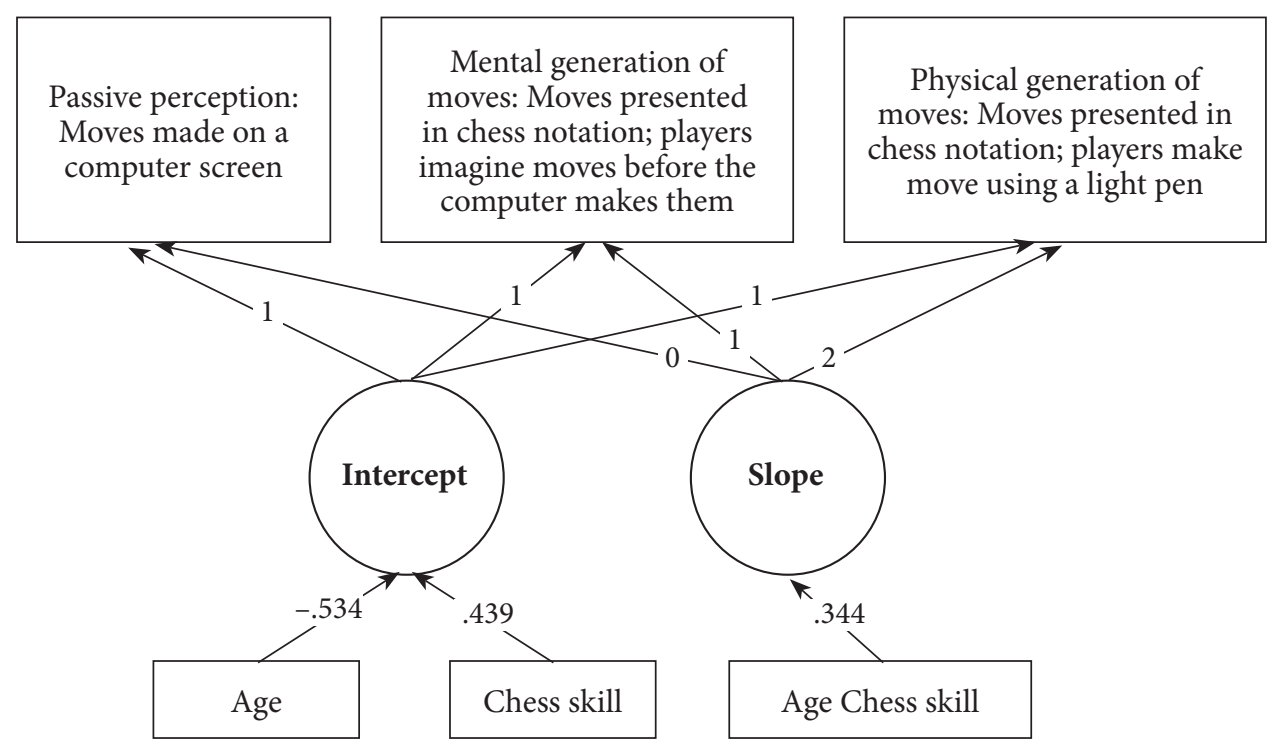

Figure 2. The structural model of the dynamics of recollecting the sequences of opening moves depending on the condition for memorizing, on age, and on the level of chess skill. $\chi^{2}=8.501, \mathrm{df}=7, p$-value $=0.29, \mathrm{CFI}=0.991, \mathrm{RMSEA}=0.075$.

\section{Discussion}

The fact that skilled chess players memorize the sequences of opening moves better than unskilled players can be explained by the large volume and better organizing structure of knowledge that they have; these factors help chess experts memorize moves. Indeed, extensive knowledge of a subject is treated as a common mechanism underlying skill in different areas (de Groot 1946/1978; Chase \& Simon 1973), and it is also considered one of the factors in masterful performance (Charness et al., 1996). In self-reports, the experienced players also stressed the positive role of general opening schemes and knowledge in memorizing sequences of moves; these players noted that they were familiar with most of the variants presented for memorizing.

The best recollecting of opening moves in the situation if memorizing is accompanied by chess players' physically executing these moves by themselves can 
be explained by the correspondence of the condition for memorizing and the condition for recollecting. The high productivity in recollecting chess moves by experts over 40 years old in these conditions may be associated with the involvement of motor memory, which appears first in phylogenesis and ontogenesis and continues longer (Blonsky 1998, Ribot, 1998). Probably in these players motor functions animate knowledge with the support of which the current recollecting is realized.

High-level memory under the condition of passive perception in the group of skilled young players is associated with the fact that masters are quicker than intermediate chess players and beginners in perceiving chess positions and encoding them (data of Chase and Simon presented by Klacki, 1998). According to Chase and Simon, chess masters are able more quickly to perceive a position on the board and to encode it, and, in addition, they more efficiently structure what they perceive. We did not conduct an analysis of the relationship between chess skill and age with features of the perception of chess positions. But it is logical to assume that with age the speed of perception and coding in skilled players can get worse and become closer to the rates for younger and less skilled players. This assumption may explain the poor results obtained in our experiments in the first series by the group of strong players over 40 . The result may have been affected by the weakening of attention with age.

Visualization by chess experts after the age of 40 gets weaker, but, like motor memory, it helps in memorizing. A. Binet (see Tikhomirov, 1967) and then I. N. D'yakov, N. V. Petrovsky, and P. A. Rudick (see D'yakov, 1926) in their first professiogram of a professional chess player indicated that imagination is an important quality of these players.

The best memorizing in the second and third series was by the older and more experienced players in comparison with the younger and less experienced ones. We can thus conclude that when the moves are done physically or mentally, skill can compensate for negative age-related changes and can have a positive effect on the memorizing of sequences of moves.

The better results in the first series for younger and less experienced players in comparison with the older and more experienced ones can be interpreted in this way: in the passive acceptance of sequences of opening moves, skill does not compensate for age-related slowing of perception and coding, which negatively affects recollection.

In general, low consistency in the actual results of memorizing and subjects' estimates of the ease of memorizing can be explained by the fact that the efforts and activity on the part of the subject in relation to any of the material enhance its being memorized (Nourkova, 2008).

The results support the activity interpretation of the principle of specificity in episodic memory, according to which aspects of information flow that correspond with previously existing activity are encoded stably. Based on the "rule of the decade" and the fact that chess skill, reliably assessed using the coefficient ELO, is determined largely by the deliberate practice of serious, independently conceived analysis (Charness et al., 1996; Charness, Tuffiash, Krampe, Reingold, \& Vasyukova, 2005; Vasyukova 2009), the principle of activity-based specificity in chess 
playing can be clarified as follows: those aspects of information flow (e.g., the sequences of chess opening moves) that correspond to the content of regularly carried out activities related to the serious, independent analysis of chess playing are encoded stably.

\section{Conclusions}

Concordance the conditions for recording and for reproducing information facilitates access to it, but in the activity, which demands a high degree of memory, factors of skill mediated by deliberate practice and of age play a more important role than this concordance the conditions in ensuring the effectiveness of recollecting.

The LCM, which reflects latent growth in recollecting depending on the condition for memorizing and which is constructed with SEM, fits well with our experimental data. In accordance with this model, the dynamic of recollecting depends for each subject on the condition for memorization; it can be presented as a linear function, which is characterized by an intercept corresponding to the level of recollecting from passive perception and by the growth rate (slope). The level of recollecting depends negatively on age and positively on training, and the growth rate depends on the interaction of the in-between factors (age and skill) and reaches the highest level for chess experts (ELO > 2000) after they are 40 years old. At the maximum correspondence of the condition for memorizing and the condition for recollecting, old experienced players show better slope of results than younger players, and under the passive-perception condition young experienced players are the best. The results confirm the unity of activity-based specificity and specificity of encoding' principles (and principle of memory' development also) in episodic memory.

\section{Acknowledgements}

This research was supported in part by NIA grant 5R01 AG13969 to Neil Charness.

\section{References}

Bartashnikov, A. A. (1988). Psihologicheskie osobennosti i formirovanie operativnoj pamjati u shkolnikov $i$ shahmatistov [Psychological characteristics and the formation of operational memory in students and chess players] (Unpublished doctoral dissertation). Moscow: NII obshhej i pedagogicheskoj psihologii APN SSSR.

Bentler, P. M. (1995). EQS structural equations program manual. Encino, CA: Multivariate Software.

Blonsky, P. P. (1998). Osnovnye predpolozhenija geneticheskoj teorii pamjati [Basic assumptions of the genetic theory of memory]. In J. B. Gippenrejter \& V. J. Romanov (Eds.), Psihologija pamjati [The psychology of memory] (pp. 380-389). Moscow: CheRo.

Blumenfeld, B. M. (1948). K harakteristike nagljadno-dejstvennogo myshlenija [To the characteristic of a visual-active thinking]. Izv. APN RSFSR, 13, 175-203. 
Bollen, K. A., \& Curran, P. J. (2006). Latent curve models: A structural equation perspective. Hoboken, NJ: Wiley-Interscience.

Charness, N., Krampe, R., \& Mayr, U. (1996). The role of practice and coaching in entrepreneurial skill domains: An international comparison of life-span chess skill acquisition. In K. A. Ericsson (Ed.), The road to excellence: The acquisition of expert performance in the arts and sciences, sports, and games (pp. 51-80). Mahwah, NJ: Erlbaum.

Charness, N., Tuffiash, M., Krampe, R., Reingold, E. M., \& Vasyukova, E. (2005). The role of deliberate practice in chess expertise. Applied Cognitive Psychology, 19, 151-165. doi: 10.1002/ acp. 1106

Chase, W. G., \& Simon, H. A. (1973). The mind's eye in chess. In W. G. Chase (Ed.), Visual information processing (pp. 215-281). New York: Academic Press.

De Groot, A. (1946/1978). Thought and choice in chess. The Hague: Mouton.

D'yakov, I. N. (1926). Psihogramma shahmatista [Psychogramme of a chess player]. Shahmaty [Chess], 4. Retrieved from http://proint.narod.ru/oldj/fromcp/psichogr.htm

Ericsson, K. A. (1996). The acquisition of expert performance: An introduction to some of the issues. In K. A. Ericsson (Ed.), The road to excellence: The acquisition of expert performance in the arts and sciences, sports, and games (pp. 1-50). Mahwah, NJ: Erlbaum.

Istomina, Z. M. (1998). Razvitie proizvol'nogo zapominanija u doshkol'nikov [The development of voluntary memory in preschoolers]. In J. B. Gippenrejter \& V. J. Romanov (Eds.), Psihologija pamjati [The psychology of memory] (pp. 653-657). Moscow: CheRo.

Klacki, R. (1998). Mnemonisty, shahmatnaja igra i pamjat' [Mnemonists, the game of chess, and memory]. In J. B. Gippenrejter \& V. J. Romanov (Eds.), Psihologija pamjati [The psychology of memory] (pp. 166-177). Moscow: CheRo.

Krogius, N. V. (1980) Poznanie ljud'mi drug druga v konfliktnoj dejatel'nosti [The knowledge of the people to each other in a conflict activity] (Unpublished doctoral dissertation). Saratov.

Kurochkina, E. V. (1997). Vlijanie neposredstvennogo obshhenija so znachimym drugim na tvorchestvo shahmatista [The influence of direct communication with a significant other on the creativity of a chess player] (Unpublished qualifying graduated work). Moscow.

Levit, L. Z. (1988). Samoocenka kak faktor reguljacii sorevnovatel'noj dejatel'nosti shahmatista [Self-evaluation as a factor in the regulation of the competitive activity of a chess player] (Unpublished doctoral dissertation). Moscow.

Mitina, O. V. (2006). Osnovnye idei i principy strukturnogo modelirovanija [The basic ideas and principles of structural modeling]. In B. S. Bratus \& E. E. Sokolova (Eds.), Uchjonye zapiski kafedry obschej psihologii MGU [Academic notes of the MSU general psychology chair] (Vol. 2, pp. 272-296). Moscow: Smysl.

Mitina, O. V. (2008). Modelirovanie latentnyh izmenenij c pomoshh'ju strukturnyh uravnenij [Modeling of the latent curve with the help of structural equations]. Eksperimentalnaja psihologija [Experimental psychology], 1, 131-148.

Nourkova, V. V. (2008). Pamjat' [Memory]. In B. S. Bratus (Ed.), Obshhaja psihologija. V 7 t:: uchebnik dlja stud. vyssh. ucheb. zavedenij [General psychology. In 7 V.: manual for students in high school institutions] (Vol.3, pp. 205-211). Moscow: Akademija. doi: 10.2753/RPO10610405490303

Nourkova, V. V. (2009). Effekt zavisimosti fenomenologicheskih harakteristik mnemicheskogo obraza ot motivacionno-smyslovoj dinamiki dejatel'nosti [The effect of the dependence of the phenomenological characteristics of a mnemonic image on the motivational-sense dynamics of the activity]. Kul'turno-Istoricheskaja Psihologija [Cultural-historical psychology], $2,60-67$. 
Nourkova, V. V. (2011). Current motivational state may change the phenomenology of recollection automatically. A new effect of activity on reported vividness and confidence. Journal of Russian and East European Psychology, 49(3), 40-54.

Ribot, T. (1998). Obschie amnezii (poteri pamjati) [General amnesia (memory loss)]. In J. B. Gippenrejter \& V. J. Romanov (Eds.), Psihologija pamjati [The psychology of memory] (pp. 54-61). Moscow: CheRo.

Tikhomirov, O. K. (1967). Struktura myslitel'noj dejatel'nosti cheloveka (opyt teoreticheskogo i jeksperimental'nogo issledovanija) [The structure of human thinking activity (the experience of theoretical and experimental research)] (Unpublished doctoral dissertation). Moscow.

Tikhomirov, O. K. (1984). Psihologija myshlenija: Uchebnoe posobie [The psychology of thinking: Educational textbook]. Moscow University Press.

Vasilyev, I. A., Popluzhnyj, V. L., Tihomirov O. K. (1980). Emocii i myshlenie [Emotions and thinking]. Moscow.

Vasyukova, E. E. (1986). Urovni razvitija poznavatel'noj potrebnosti i ih projavlenie v myslitel'noj dejatelnosti [Levels of the development of cognitive need and their manifestation in thinking activity] (Unpublished doctoral dissertation). Moscow.

Vasyukova, E. E. (1995). Razvitie poznavatel'noj potrebnosti i kreativnosti myshlenija shahmatistov [The development of cognitive need and the creative thinking of chess players]. Psihologicheskij zhurnal [Psychological journal], 1, 91-101.

Vasyukova, E. E. (1999). Psihologicheskie sostavljajushhie shahmatnogo tvorchestva (na materiale sravnenija shahmatnoj igry dvuh shahmatistov i shahmatista s komp'juterom) [Psychological components of chess creativity (comparison of the chess playing of two chess players and a chess player with a computer)]. Psihologicheskij zhurnal [Psychological journal], 3, $70-80$.

Vasyukova, E. E. (2001). Verbalizovannye operacional'nye smysly i ih razvitie v processe reshenija (na materiale vybora luchshego hoda $\mathrm{v}$ shahmatnoj pozicii) [Verbalized operational senses and their development in the process of decision making (the search for the best move in a chess position)]. Psihologicheskij zhurnal [Psychological journal], 6, 30-41.

Vasyukova, E. E. (2008). Priroda shahmatnogo masterstva [The nature of chess skill]. In Sovremennaja psihologija myshlenija: Smysl v poznanii [The modern psychology of thinking: Sense in knowledge] (abstracts of reports from a scientific conference dedicated to the 75th anniversary of the birth of the outstanding Russian psychologist O. K. Tikhomirov, 19332001, Moscow, October 17-18, 2008) (pp. 173-176). Moscow: Smysl.

Vasyukova, E. E. (2009a). Mezhsituativnyj perenos verbalizovannyh operacional'nyh smyslov pri reshenii myslitel'nyh zadach [Intersituation transfer of verbalized operational senses in the process of solving thinking problems]. Psihologicheskij zhurnal [Psychological journal], 30(6), 51-65.

Vasyukova, E. E. (2009b). Problemy razvitija i sohranenija shahmatnogo masterstva [Problems in the development and preservation of chess skill]. In L. I. Larionova (Ed.), Psihologicheskie problemy odarennosti: Teorija i praktika: Materialy VI Mezhd. konf. [Psychological problems of gifted children: Theory and practice: Materials of the 6th International Conference. In 2 v.] (Vol. 2, pp. 272-286). Irkutsk: Irkutsk. gos. lingv. un-t.

Vasyukova, E. E. (2012a). Poznanie, oposredstvovannoe informacionno-poiskovymi shahmatnymi sistemami [Cognition as mediated by informational-research chess systems]. In A. E. Voiskounsky \& L. M. Dubovoj (Eds.), Chelovek v informacionnom obshhestve: Sbornik nauchny statej po materialam Mezhdunarodnoj nauchno-prakticheskoj konferencii 31 maj-1 ijunja 2012 goda [People in the information society: A collection of scientific articles on 
the materials of the International Scientific-Practical Conference on May 31-June 1, 2012] (pp. 102-111). Penza: V. G. Belinskij PGPU.

Vasyukova, E. E. (2012b). Razvitie shahmatnogo masterstva: Problemy, principy, metody [The development of chess skills: Problems, principles, and methods]. Sportivnyj psiholog [Sport psychologist], 2, 9-15.

Velichkovsky, B. M. (2006). Kognitivnaja nauka: Osnovy psihologii poznanija [Cognitive science: The basic psychology of cognition] Moscow: Smysl; Izdatel'skij centr Akademija.

Vinogradov, Ju. E. (1972). Emocional'naja aktivacija v strukture myslitel'noj dejatel'nosti chelove$k a$ [Emotional activation in the structure of mental activity of man] (Unpublished doctoral dissertation). Moscow.

Zinchenko, P. I. (1998). Neproizvol'noe zapominanie i dejatel'nost' [Involuntary memorization and activity]. In J. B. Gippenrejter \& V. J. Romanov (Eds.), Psihologija pamjati [The psychology of memory] (pp. 465-475). Moscow: CheRo.

Received: 15 October 2013

Accepted: 05 November 2013

Available online: 15 December 2013 